\title{
Endurance of Nafion-composite membranes in PEFCs operating at elevated temperature under low relative-humidity
}

\author{
A K SAHU ${ }^{\mathrm{a}}$, A JALAJAKSHI ${ }^{\mathrm{a}}$, S PITCHUMANI ${ }^{\mathrm{a}}$, P SRIDHAR ${ }^{\mathrm{a}}$ and A K SHUKLA ${ }^{\mathrm{b}, *}$ \\ ${ }^{a}$ CSIR-Central Electrochemical Research Institute-Madras Unit, CSIR Madras Complex, Taramani, \\ Chennai, 600 113, India \\ ${ }^{\mathrm{b}}$ Solid State and Structural Chemistry Unit, Indian Institute of Science, Bangalore, 560 012, India \\ e-mail: akshukla2006@gmail.com
}

MS received 11 July 2011; revised 12 September 2011; accepted 19 October 2011

\begin{abstract}
PEFCs employing Nafion-silica (Nafion-SiO 2 ) and Nafion-mesoporous zirconium phosphate (Nafion-MZP) composite membranes are subjected to accelerated-durability test at $100^{\circ} \mathrm{C}$ and $15 \%$ relative humidity $(\mathrm{RH})$ at open-circuit voltage (OCV) for $50 \mathrm{~h}$ and performance compared with the PEFC employing pristine Nafion-1135 membrane. PEFCs with composite membranes sustain the operating voltage better with fluoride-ion-emission rate at least an order of magnitude lower than PEFC with pristine Nafion-1135 membrane. Reduced gas-crossover, fast fuel-cell-reaction kinetics and superior performance of the PEFCs with Nafion$\mathrm{SiO}_{2}$ and Nafion-MZP composite membranes in relation to the PEFC with pristine Nafion-1135 membrane support the long-term operational usage of the former in PEFCs. An 8-cell PEFC stack employing Nafion- $\mathrm{SiO}_{2}$ composite membrane is also assembled and successfully operated at $60^{\circ} \mathrm{C}$ without external humidification.
\end{abstract}

Keywords. Nafion- $\mathrm{SiO}_{2}$ composite; nafion-MZP composite; nafion-1135; fluoride-ion-emission rate; gas-crossover; polymer electrolyte fuel cell.

\section{Introduction}

Commercial viability of polymer electrolyte fuel cells (PEFCs) demands performance durability of its components. During prolonged operations, primary causes for performance deterioration of PEFCs are found to be platinum sintering, platinum dissolution and deposition in the membrane, carbon-support corrosion, and membrane thinning. ${ }^{1-6}$ These factors affect efficiency of PEFCs and result in system failure due to massive fuel-crossover across the membrane electrolyte. Nafion-type perfluorosulfonic acid (PFSA) polymers have been extensively used as membrane electrolytes in PEFCs owing to their good chemical, mechanical and thermal stability. ${ }^{7}$ In these membranes, each proton carries several molecules of water and moves through the membrane under electro-osmotic drag. Accordingly, proton conductivity of the membrane depends on the presence of water molecules to solvate protons from the sulfonic-acid groups. During PEFC operation, electroosmotic drag causes dehydration of the membrane at the anode side with consequent decrease in conductivity, especially at low relative-humidity $(\mathrm{RH})$ values. Besides, dry-out of the anode catalyst-layer is found

\footnotetext{
*For correspondence
}

to limit the maximum current-densities, especially with the thicker membranes. ${ }^{8}$ Break-down of membrane at elevated temperatures and low RH values significantly deteriorates the PEFC performance. Accordingly, operation of PEFCs with Nafion membrane is restricted to low temperatures $\left(<80^{\circ} \mathrm{C}\right.$ ) and high $\mathrm{RH}$ values (ca. $100 \% \mathrm{RH})$ so as to retain the characteristics of Nafion membrane.

During accelerated PEFC tests, membrane degradation can occur much faster than under normal operating conditions. Membrane degradation is often monitored by changes in gas-crossover rate or fluorideion-emission rate (FER) in PEFCs during their operation. ${ }^{8,9}$ PEFCs operating at elevated temperatures are especially desirable for automotive applications owing to heat rejection issues that demand the search for membranes with high-temperature stability. ${ }^{9,11}$ In addition, PEFC operation under low RH values at open-circuit voltage $(\mathrm{OCV})$ causes membrane degradation as hydrogen peroxide generation is accelerated at OCV. ${ }^{12-15}$

Membrane degradation could be mitigated by reducing reactant crossover by cross-linking the membrane, and by increasing membrane thickness and crystallinity. ${ }^{16}$ However, in all these approaches, there is a trade-off since the increase in membrane resistance affects the PEFC performance. PFSA membranes with improved chemical, mechanical and thermal stability as 
well as proper water management at high temperatures are possible to achieve by forming a composite. Endoh et $a l^{17}$ have developed a PFSA-based composite membrane with excellent stability at $\mathrm{OCV}$ at $120^{\circ} \mathrm{C}$ and $18 \%$ $\mathrm{RH}$. Interestingly, FER for such a membrane is about $2 \times 10^{-8} \mathrm{~g} \mathrm{~cm}^{-2} \mathrm{~h}^{-1}$, which is less than $1 \%$ of the FER under OCV for the Nafion-based MEA.

Hydrogen crossover is undesirable diffusion of hydrogen from anode to cathode through the membrane and can have adverse effect on PEFC at least in three ways: (i) reduction in fuel efficiency, (ii) depression in cathode potential, and (iii) severe formation of peroxide radicals at the cathode, which not only damage the catalyst layer but also the membrane. ${ }^{18}$ In addition, it is also reported that formation of hydrogen peroxide is an exothermic reaction that results in pin-holes in the membranes, destroying the membrane electrode assembly (MEA) and causing safety problems. ${ }^{19-21}$ Therefore, measurement of hydrogen crossover, in particular at OCV where most severe crossover occurs, is of utmost importance in a PEFC. In general, fuel crossover could be reduced if small particles are present in the ionic clusters of the membrane-forming composites. The ionic clusters force gas molecules along a tortuous pathway that reduces the fuel crossover and enhances the membrane durability. Furthermore, interconnection of these particles with ionic sites maintains proton conductivity and provides mechanical reinforcement with good stability.

In the present study, accelerated durability test is conducted on a PEFC employing pristine Nafion-1135 membrane under stringent operating conditions, namely at $100^{\circ} \mathrm{C}$ and $15 \% \mathrm{RH}$ at $\mathrm{OCV}$, for $50 \mathrm{~h}$. During accelerated test, rapid fall in voltage with high fluoride-ion emission rate causes membrane damage with high gascrossover rate affecting fuel cell performance. In contrast, PEFCs with Nafion-SiO ${ }_{2}$ and Nafion-MZP composite membranes on subjecting to aforesaid accelerated test are found to possess higher stability in relation to PEFC with pristine Nafion-1135 membrane. The composite membranes with inorganic fillers, such as $\mathrm{SiO}_{2}$ and MZP, have high affinity to water, facilitating proton conduction even at elevated temperatures and low RH values. This enables the PEFCs to be operated at elevated temperatures even under low RH levels. An 8-cell PEFC stack employing Nafion- $\mathrm{SiO}_{2}$ composite membranes is assembled and successfully operated at $60^{\circ} \mathrm{C}$ without external humidification.

\section{Experimental}

Nafion-silica (10 wt.\%) composite membranes were obtained by impregnating silica by a novel water hydrolysis sol-gel process. ${ }^{22}$ Nafion-MZP (5 wt.\%) composite membranes were prepared by impregnating MZP powder synthesized by a co-assembly route using Pluronic-F127 as a structure-directing agent. ${ }^{23}$ Pretreated Nafion-1135 membranes (DuPont) were used for comparison.

For realizing MEAs, diffusion-layer coated carbon papers (SGL, thickness $=0.27 \mathrm{~mm}$ ) were used as gasdiffusion layer (GDL). For the catalyst layer, $40 \mathrm{wt} . \%$ $\mathrm{Pt} / \mathrm{C}$ (Johnson Matthey) was dispersed in a mixture of 2-propanol and Nafion solution followed by ultrasonication for $20 \mathrm{~min}$ to form a homogeneous slurry that was applied onto the GDL. The catalyst loadings on both anode and cathode (active area: $25 \mathrm{~cm}^{2}$ ) were kept at $0.5 \mathrm{mg} \mathrm{cm}^{-2}$. A thin layer of Nafion ionomer was applied to the catalyst surface of both the electrodes and MEAs were obtained by hot pressing the Nafion-1135 membrane sandwiched between cathode and anode under $15 \mathrm{kN}\left(\sim 60 \mathrm{~kg} \mathrm{~cm}^{-2}\right)$ at $125^{\circ} \mathrm{C}$ for 3 min. In a similar manner, MEAs with Nafion- $\mathrm{SiO}_{2}$ and Nafion-MZP membranes were obtained. Subsequently, MEAs were coupled with Teflon gas-sealing gaskets and placed in a single-cell test fixture with parallel serpentine flow-field machined on graphite plates. The PEFCs employing pristine Nafion-1135 membrane and Nafion composite membranes were evaluated at $75^{\circ} \mathrm{C}$ with $\mathrm{H}_{2}(83 \% \mathrm{RH})-\mathrm{O}_{2}(83 \% \mathrm{RH})$ and $\mathrm{H}_{2}(83 \%$ $\mathrm{RH})$ - air $(60 \% \mathrm{RH})$, and the values were recorded prior to the durability test using an Arbin Fuel Cell Test Station (Model PEM-FCTS-158541, US). PEFCs were subsequently conditioned at $100^{\circ} \mathrm{C}$ and $15 \% \mathrm{RH}$ in $\mathrm{H}_{2}$-air feed for accelerated durability test at $\mathrm{OCV}$ for $50 \mathrm{~h}$ and the voltage drops for all the cells were recorded. During the test, anode and cathode condensates were independently collected in cold-traps for each cell. Fluoride-ion concentrations in the condensate water were measured, using a Thermo Scientific Orion $\mathrm{Star}^{T M}$ Series Meter, after calibration.

The hydrogen crossover was determined by linearsweep voltammetry (LSV) technique using a potentiostat (Autolab PGSTAT 30) at room temperature $\left(\sim 25^{\circ} \mathrm{C}\right)$ prior and after PEFC durability test. For this purpose, the cells were purged with hydrogen at the anode and nitrogen at the cathode. In this mode, the fuel cell anode serves as reference while the counter electrode and the fuel cell cathode act as the working electrode in the three-electrode configuration. Hydrogen supplied to the anode permeates through the membrane and reaches the cathode, where it is electrochemically oxidized. The detected current resulting from the oxidation of molecular hydrogen at fuel cell cathode is termed as hydrogen-crossover limiting current. For $\mathrm{LSV}$, the potential was scanned from $0.1 \mathrm{~V}$ to $0.4 \mathrm{~V}$ at 
a sweep rate of $2 \mathrm{mV} \mathrm{s}^{-1}$. The crossover current was determined at the steady-state voltage range between $0.3 \mathrm{~V}$ and $0.35 \mathrm{~V}$. For measurement of the electrochemical surface area (ESA) of the catalyst, cyclic voltammograms (CVs) were recorded under conditions described above between $0 \mathrm{~V}$ and $1 \mathrm{~V}$ at a sweep rate of $50 \mathrm{mV}$ $\mathrm{s}^{-1}$ prior and after durability test.

In situ impedance spectra were also obtained under fuel-cell-operating conditions with a load currentdensity of $200 \mathrm{~mA} / \mathrm{cm}^{2}$ prior and after durability test. The frequency ranges were selected between $5 \mathrm{kHz}$ and $0.1 \mathrm{~Hz}$ with $15 \mathrm{mV}$ amplitude using Autolab PGSTAT $128 \mathrm{~N}$ with NOVA software. During the impedance measurements, the cells were operated at room temperature $\left(\sim 25^{\circ} \mathrm{C}\right)$ without humidifying the reactants. The resistance value associated with the membrane was determined from the high-frequency intercept of the impedance with the real axis.

Based on the fuel cell performance and durability data, it was established that Nafion composite membranes exhibit better properties compared to pristine Nafion-1135 membrane. Nafion-silica composite membranes of dimension $15 \mathrm{~cm} \times 15 \mathrm{~cm}\left(=225 \mathrm{~cm}^{2}\right)$ were fabricated and MEAs were realized accordingly, and an 8-cell PEFC stack was assembled with electrode activearea of $140 \mathrm{~cm}^{2}$. The configurations of $140 \mathrm{~cm}^{2}$ MEAs were similar to $25 \mathrm{~cm}^{2}$ MEAs with catalyst loadings of $1 \mathrm{mg} \mathrm{cm}^{-2}$ and $0.5 \mathrm{mg} \mathrm{cm}^{-2}$ maintained on cathode and anode, respectively. The 8-cell PEFC stack employing Nafion-silica composite membranes was assembled and performance evaluated with dry $\mathrm{H}_{2}$ at anode and atmospheric air passed through a humidity exchanger at cathode of the stack. Individual cell potentials of the stack were recorded at varying load current-densities for determining the consistency of MEAs.

\section{Results and discussion}

Nafion-silica composite membrane is fabricated by a novel sol-gel route as described elsewhere. ${ }^{22}$ In brief, homogeneous and transparent silica sol is first prepared by controlled water hydrolysis of tetra-ethoxy-orthosilicate (TEOS) by an in situ sol-gel process. Subsequently, the required amount of the sol is incorporated into the polymer matrix. The sol enters the fine pores of PFSA and due to the acidic nature of the latter forms $\mathrm{Si}-\mathrm{OH}$ network in the pores, which on heating at $90^{\circ} \mathrm{C}$ under vacuum culminate as $\mathrm{Si}-\mathrm{O}-\mathrm{Si}$ linkages forming a film of nearly the same thickness $(\sim 90 \mu \mathrm{m})$ as Nafion1135. The resultant polymer film is visibly transparent and has no particle/phase segregation. This process has distinct advantages over other conventional methods of making composite membranes. ${ }^{24-28}$

In contrast, the rapid hydrolysis and polymerization reaction while preparing zirconia sol results in uncontrolled thickness and volume reduction in the composite membrane. Accordingly, for fabricating NafionMZP composite membrane, MZP powders are first prepared using a structure-directing cationic surfactant (Pluronic-F127) by a co-assembly route and subsequently mixed with Nafion ionomer for fabricating composite membranes. ${ }^{23}$ Zirconia has sphere-like irregular porous structure in the composite membrane. MZP acts as surface-functionalised-solid-superacid-protonconducting medium as well as inorganic filler with high affinity to absorb water and facilitates fast protontransport across the electrolyte membrane as desired for PEFC operation. This process has many advantages over other conventional methods for preparing composite membranes. ${ }^{29-31}$

PEFCs employing pristine Nafion-1135, Nafion$\mathrm{SiO}_{2}$ and Nafion-MZP membranes are conditioned at $100^{\circ} \mathrm{C}$ with $15 \% \mathrm{RH}$ for the accelerated durability test at OCV for $50 \mathrm{~h}$ and the data are shown in figure 1. During $50 \mathrm{~h}$ of operation, the PEFC employing pristine Nafion-1135 membrane exhibits a voltage drop of about $150 \mathrm{mV}$ as against only $\sim 20 \mathrm{mV}$ for the PEFCs employing Nafion- $\mathrm{SiO}_{2}$ and Nafion-MZP composite membranes. This is attributed to reduced fuel-crossover across composite membranes due to the presence of hydrophilic inorganic fillers that provide better water retention in the composite membranes and make the composite membranes less susceptible

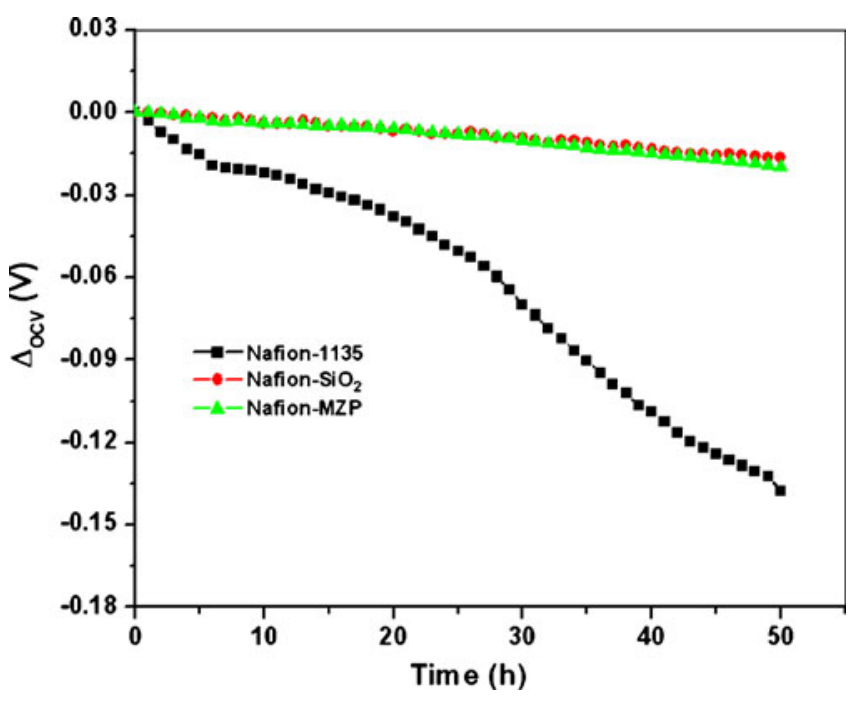

Figure 1. Change in OCV $\left(\triangle_{O C V}\right)$ with time for the PEFCs employing pristine Nafion-1135, Nafion- $-\mathrm{SiO}_{2}$ and Nafion-MZP composite membranes at $100^{\circ} \mathrm{C}$ and $15 \% \mathrm{RH}$. 
to structural damage, and help mitigating the shrinkage of membranes even at low RH values. This is further supported by reduced fluoride-ion emission rate (FER) and hydrogen crossover current for the composite membranes in relation to the pristine Nafion-1135 membrane.

Figure 2 depicts FER data on by-product water collected from anode and cathode exhausts during $50 \mathrm{~h}$ of stability test for PEFCs employing pristine Nafion-1135, Nafion-SiO ${ }_{2}$ and Nafion-MZP composite membranes. The FER values for PEFCs employing composite membranes on both anode and cathode exhausts are significantly lower in relation to the FER value for PEFC employing pristine Nafion-1135 membrane. Incorporating $\mathrm{SiO}_{2}$ or MZP to the Nafion matrix increases the membrane chemical stability and hinders fuel crossover that reduces $\mathrm{H}_{2} \mathrm{O}_{2}$ formation on the cathode side.

Figure 3 represents hydrogen-crossover current density for the PEFCs employing pristine Nafion-1135, Nafion- $\mathrm{SiO}_{2}$ and Nafion-MZP composite membranes prior and after the durability test. The hydrogen crossover current data are culled from figure 3 and are also presented in table 1. Crossover current for all the membranes are nearly similar prior to the durability test. However, the hydrogen cross-over current is about 3 times higher for pristine Nafion-1135 membrane after durability test. This indicates that fatal damage to membrane could be due to membrane thinning and/or formation of micro-holes during the course of durability test. By contrast, hydrogen-crossover currents for Nafion- $\mathrm{SiO}_{2}$ and Nafion-MZP composite membranes show only a marginal increase after durability test. The presence of inorganic fillers in the ionic clusters of Nafion matrix restricts fuel crossover as

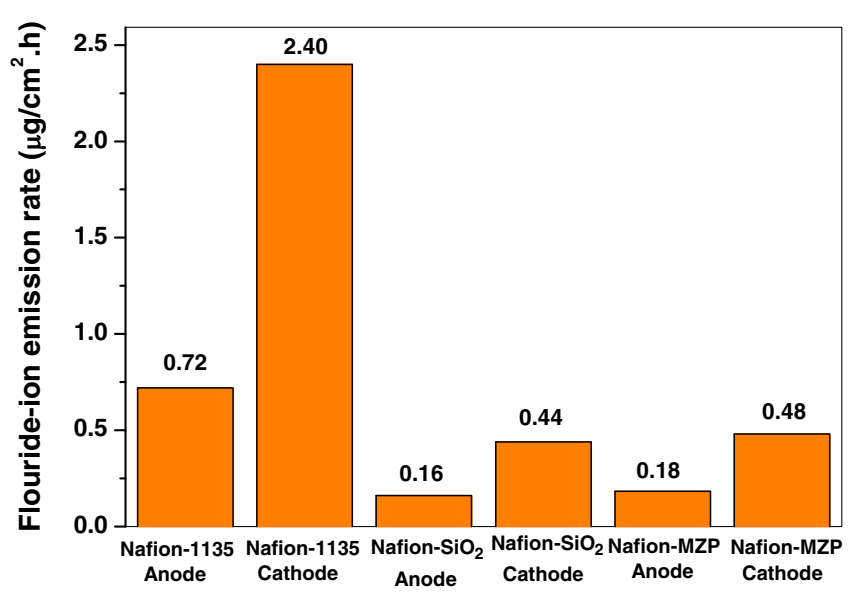

Figure 2. Fluoride-ion emission rates at anode and cathode for the PEFCs employing pristine Nafion-1135, Nafion-SiO and Nafion-MZP composite membranes after durability test.

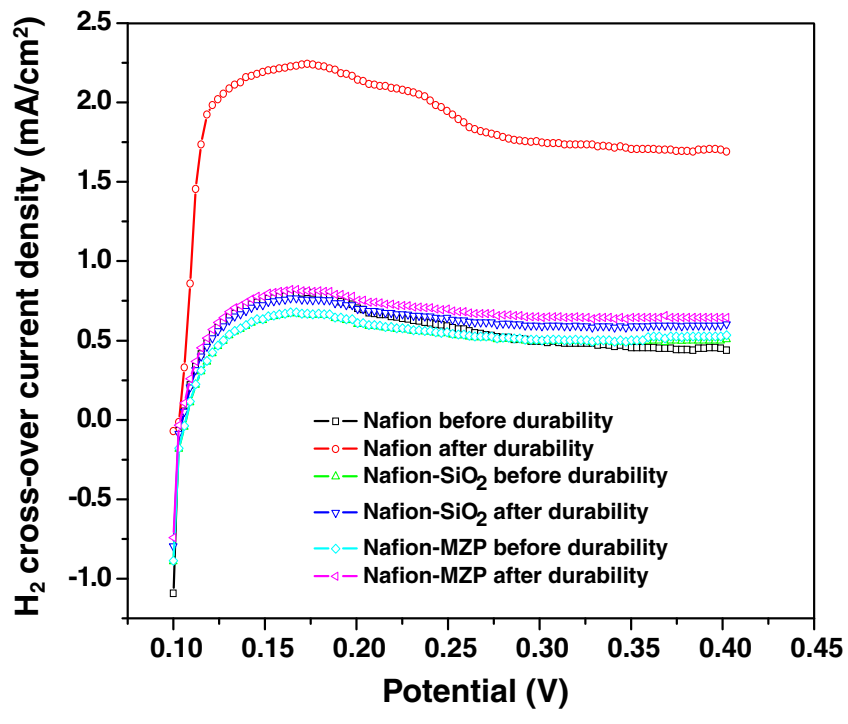

Figure 3. Hydrogen cross-over current for the PEFCs employing pristine Nafion-1135, Nafion- $\mathrm{SiO}_{2}$ and NafionMZP composite membranes prior and after durability test.

the molecular hydrogen is made to follow a tortuous path across the composite membranes. Furthermore, the inter-connection of these fillers with ionic sites provides good proton conductivity with mechanical stability.

Figure 4 shows in situ impedance spectra for PEFCs employing pristine Nafion-1135, Nafion-SiO $\mathrm{S}_{2}$ and Nafion-MZP composite membranes prior and after durability test at a load current-density of $200 \mathrm{~mA}$ $\mathrm{cm}^{-2}$. Nyquist plot obtained in the present study has only a single arc which basically reflects the cathodic impedance as the reaction kinetics for hydrogen oxidation reaction is relatively faster. Besides, the interest in the present study is to find the deviation in the $\mathrm{R}_{s}$ value of the membrane during the endurance/durability test. Accordingly, typical Randles equivalent circuit is used. The impedance spectra with pristine Nafion-1135 membrane shows wide variation in $R_{h f}$ and $R_{c t}$ values prior and after durability test in relation to the composite membranes (table 1). The lack of water molecules at elevated temperature and low humidity cause physical damage to the membrane with Pt catalyst sintering and/or destruction of three-phase boundaries. The Nyquist plot for pristine Nafion-1135 membrane after durability test shows $45^{\circ}$ branch reflecting the coupling of distributed ionic resistance and capacitance in the catalyst layer primarily due to limited proton conductivity. Furthermore, a possible cause for the increased $R_{c t}$ at high temperatures could be due to reduction of water content in the catalyst layer. By contrast, in case of composite membranes, due to the presence of hydrophilic filler materials, membrane and catalyst layer wettability is maintained which in turn has very little effect on 
Table 1. High-frequency resistance $\left(\mathrm{R}_{\mathrm{hf}}\right)$, charge-transfer resistance $\left(\mathrm{R}_{\mathrm{ct}}\right)$, hydrogen cross-over current and ESA of cathode catalyst for the MEAs with Nafion-1135, Nafion- $\mathrm{SiO}_{2}$ and Nafion-MZP membranes before and after durability tests.

\begin{tabular}{|c|c|c|c|c|c|c|c|c|}
\hline \multirow[b]{2}{*}{$\begin{array}{l}\text { Membrane } \\
\text { type }\end{array}$} & \multicolumn{2}{|c|}{$\begin{array}{c}\mathrm{R}_{\mathrm{hf}} \\
\left(\Omega \mathrm{cm}^{2}\right)\end{array}$} & \multicolumn{2}{|c|}{$\begin{array}{c}\mathrm{R}_{\mathrm{ct}} \\
\left(\Omega \mathrm{cm}^{2}\right)\end{array}$} & \multicolumn{2}{|c|}{$\begin{array}{l}\mathrm{H}_{2 \text { cross-over current }} \\
\left(\mathrm{mA} \mathrm{cm}^{-2}\right)\end{array}$} & \multicolumn{2}{|c|}{$\operatorname{ESA}\left(\mathrm{m}^{2} \mathrm{~g}^{-1}\right)$} \\
\hline & $\begin{array}{c}\text { Before } \\
\text { durability }\end{array}$ & $\begin{array}{c}\text { After } \\
\text { durability }\end{array}$ & $\begin{array}{c}\text { Before } \\
\text { durability }\end{array}$ & $\begin{array}{c}\text { After } \\
\text { durability }\end{array}$ & $\begin{array}{c}\text { Before } \\
\text { durability }\end{array}$ & $\begin{array}{c}\text { After } \\
\text { durability }\end{array}$ & $\begin{array}{c}\text { Before } \\
\text { durability }\end{array}$ & $\begin{array}{c}\text { After } \\
\text { durability }\end{array}$ \\
\hline Nafion-1135 & 0.16 & 0.22 & 0.26 & 2.24 & 0.50 & 1.74 & 100 & 56.5 \\
\hline Nafion- $\mathrm{SiO}_{2}$ & 0.15 & 0.16 & 0.24 & 0.77 & 0.47 & 0.59 & 100 & 99.0 \\
\hline Nafion-MZP & 0.15 & 0.16 & 0.24 & 0.82 & 0.48 & 0.65 & 100 & 97.1 \\
\hline
\end{tabular}

$\mathrm{R}_{\mathrm{hf}}$ and $\mathrm{R}_{\mathrm{ct}}$ values after durability test. Cyclic voltammograms are also recorded to measure electrochemical surface area (ESA) of catalyst prior and after durability test. For PEFC comprising Nafion-1135 membrane, the ESA of the cathode catalyst is $100 \mathrm{~m}^{2} \mathrm{~g}^{-1}$ and $56.5 \mathrm{~m}^{2} \mathrm{~g}^{-1}$ prior and after durability test, respectively. Operating the PEFC both at elevated temperature and low RH during durability tests brings about a reduction in the ESA value due to growth of Pt particles. ${ }^{32}$ However, in the PEFCs comprising pristine Nafion- $\mathrm{SiO}_{2}$ and Nafion-MZP composite membranes, a negligible change in ESA is observed due to high hydration level maintained by inorganic particles leading to proper water management in the MEAs.

The performance data for pristine Nafion-1135, Nafion- $\mathrm{SiO}_{2}$ and Nafion-MZP composite membranes prior and after durability test at $75^{\circ} \mathrm{C}$ with $\mathrm{H}_{2}(83 \%$ $\mathrm{RH})$ and $\mathrm{O}_{2}(83 \% \mathrm{RH})$ are shown in figure 5. The peak-power densities for the PEFCs with pristine Nafion-1135, Nafion-SiO $\mathrm{S}_{2}$ and Nafion-MZP composite membranes are $770 \mathrm{~mW} \mathrm{~cm} \mathrm{~cm}^{-2}, 866 \mathrm{~mW} \mathrm{~cm}^{-2}$

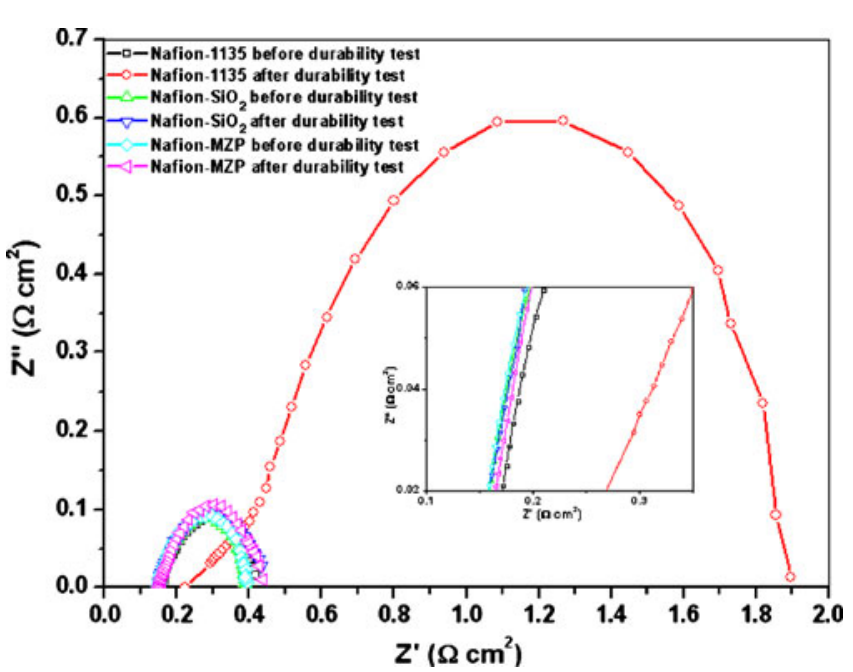

Figure 4. Nyquist plot for the PEFCs employing pristine Nafion-1135, Nafion-SiO ${ }_{2}$ and Nafion-MZP composite membranes prior and after durability test at $200 \mathrm{~mA} / \mathrm{cm}^{2}$. and $800 \mathrm{~mW} \mathrm{~cm} \mathrm{~cm}^{-2}$ respectively. Superior performance for PEFCs with composite membranes are due to the presence of positively-charged silica and zirconia particles which counter balance the negatively-charged sulphonate groups present in Nafion enhancing the hydrophilicity of the composite membranes. The longrange coulombic attractive forces between protons and sulphonate groups are disrupted by the presence of positively-charged silica and zirconia particles in the membrane, facilitating the protons to readily pass through the membrane pores. ${ }^{23}$ Performance of the PEFC with pristine Nafion-1135 membrane drastically reduces after durability test due to continuous operation under low $\mathrm{RH}$ and at elevated temperature causing physical deformation of the membrane. However, the presence of hydrophilic materials, such as $\mathrm{SiO}_{2}$ and MZP, helps holding water and keeps composite membranes hydrated. Accordingly, Nafion- $\mathrm{SiO}_{2}$ and Nafion-MZP composite membranes do not suffer temperature and humidity-related structural deformation

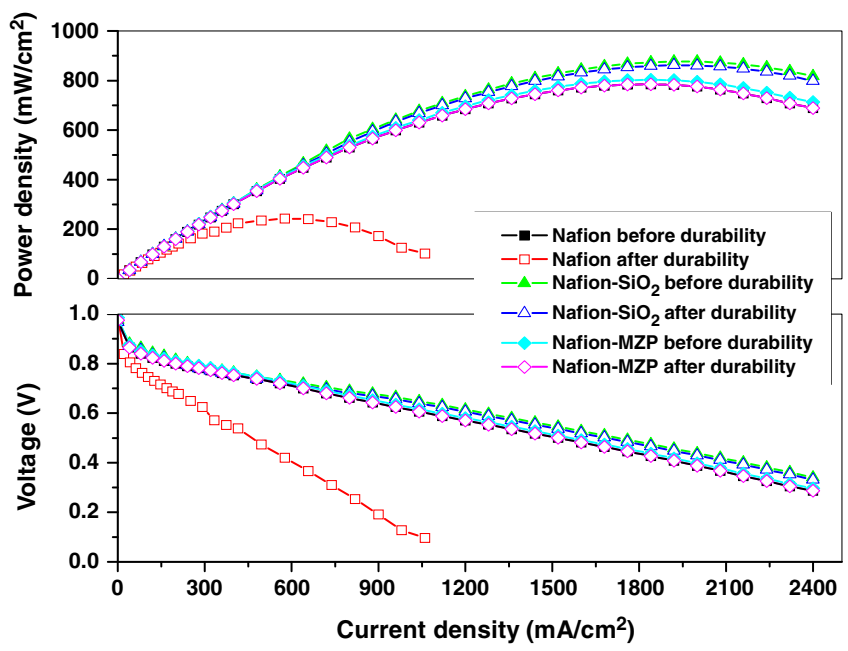

Figure 5. Polarization curves for the PEFCs employing pristine Nafion-1135, Nafion- $\mathrm{SiO}_{2}$ and Nafion-MZP composite membranes prior and after durability test at $75^{\circ} \mathrm{C}$ with $\mathrm{H}_{2}(83 \% \mathrm{RH})$ and $\mathrm{O}_{2}(83 \% \mathrm{RH})$. 
and show little variation in fuel cell performance prior and after durability test.

Figure 6 shows the performance curves for the PEFCs comprising pristine Nafion-1135, Nafion-SiO and Nafion-MZP composite membranes prior and after durability test at $75^{\circ} \mathrm{C}$ with $\mathrm{H}_{2}(83 \% \quad \mathrm{RH})$ and air $(60 \% \mathrm{RH})$. The peak-power densities prior to the durability test for the PEFCs with pristine Nafion-1135, Nafion-SiO $\mathrm{S}_{2}$ and Nafion-MZP composite membranes are $535 \mathrm{~mW} \mathrm{~cm}{ }^{-2}, 625 \mathrm{~mW} \mathrm{~cm}^{-2}$ and $610 \mathrm{~mW} \mathrm{~cm}^{-2}$, respectively. At high load currentdensities, for the PEFC with pristine Nafion-1135 membrane, the water generation rate at the cathode is too high to substantially affect the effective area of the gas-diffusion layers restricting the permeation of reactant gases to the active catalyst sites. However, the high water-uptake by Nafion- $\mathrm{SiO}_{2}$ and Nafion-MZP composite membranes hydrates the membranes with the product water and mitigates water flooding in the PEFCs. After durability test in stringent operating conditions for a prolonged period, the PEFC comprising pristine Nafion-1135 membrane shows drastic reduction in performance, while the performance of PEFCs with composite membranes has little effect. These data further support superior properties of the composite membranes and their suitability as durable membranes for PEFCs operating at elevated temperature and reduced $\mathrm{RH}$. In contrast, the performance of the PEFC with pristine Nafion-1135 membrane deteriorates due to poor dimensional and structural stability.

From the foregoing, it is concluded that Nafioncomposite membranes exhibit better performance at

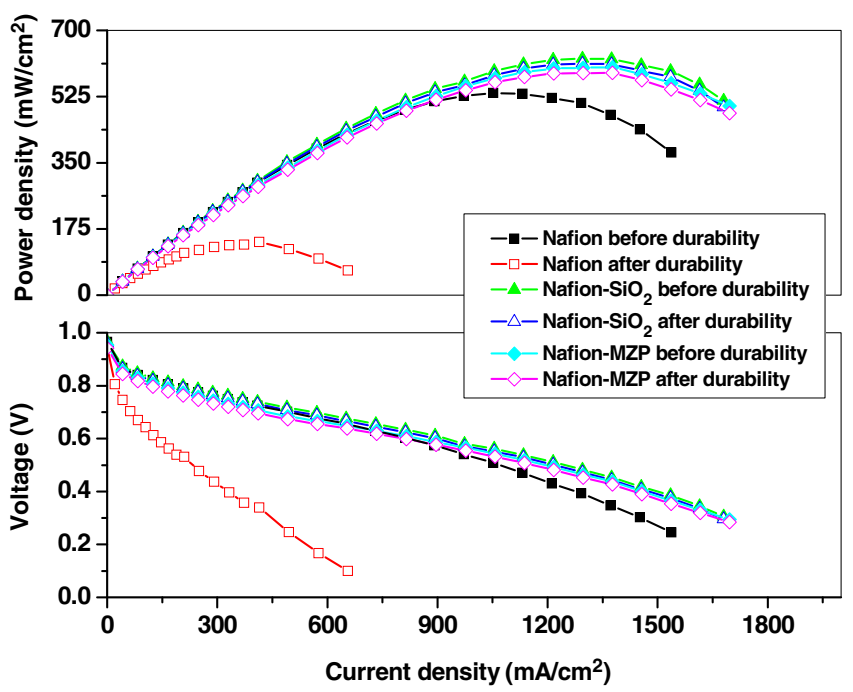

Figure 6. Polarization curves for PEFCs employing pristine Nafion-1135, Nafion-SiO $\mathrm{S}_{2}$ and Nafion-MZP composite membranes prior and after durability test at $75^{\circ} \mathrm{C}$ with $\mathrm{H}_{2}$ $(83 \% \mathrm{RH})$ and Air $(60 \% \mathrm{RH})$. elevated temperature and low humidity under stringent operating conditions. The performance of Nafionsilica composite membrane is superior when compared to all the membranes studied here. This may be due to impregnation of silica into Nafion matrix in the form of a sol by a novel water hydrolysis sol-gel process leading to a uniform and homogeneous composite membrane without any phase separation. In contrast, for fabricating Nafion-MZP composite membranes, the MZP powder is first prepared by a co-assembly route and mixed with Nafion ionomer for casting composite membranes. During the process, the particles are uniformly dispersed in Nafion matrix but a phase separation is observed. ${ }^{33}$ Accordingly, suitability of Nafionsilica composite membrane for its operation without external humidification in a PEFC stack is studied. For this purpose, Nafion-silica membranes of $225 \mathrm{~cm}^{2}$ area are cast and an 8-cell PEFC stack with an active flowfield area of $140 \mathrm{~cm}^{2}$ is assembled. The stack is performance tested without external humidification. In the stack, atmospheric air is fed to the cathode through a humidity exchanger (internal membrane-humidifier)
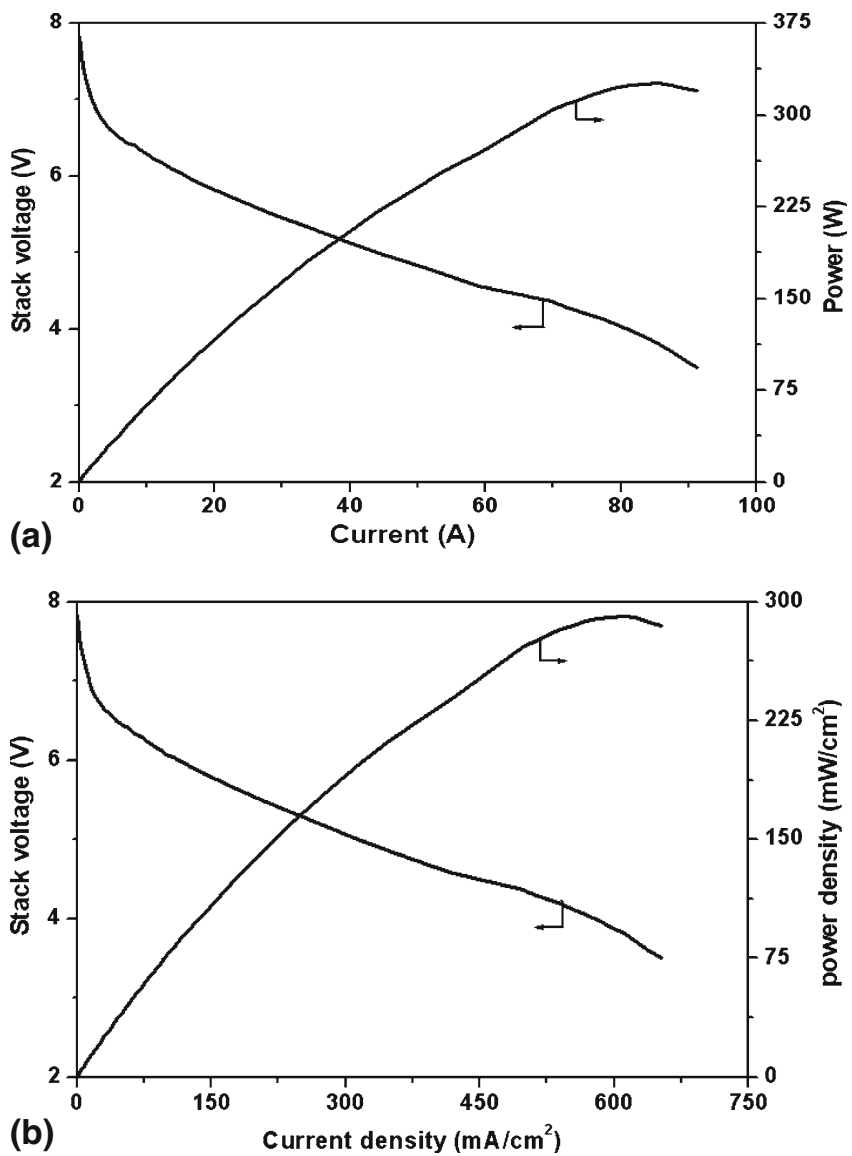

Figure 7. (a) and (b) are power and power density curves for the Nafion-silica 8-cell PEFC stack operating at $60^{\circ} \mathrm{C}$ without any external humidification. 


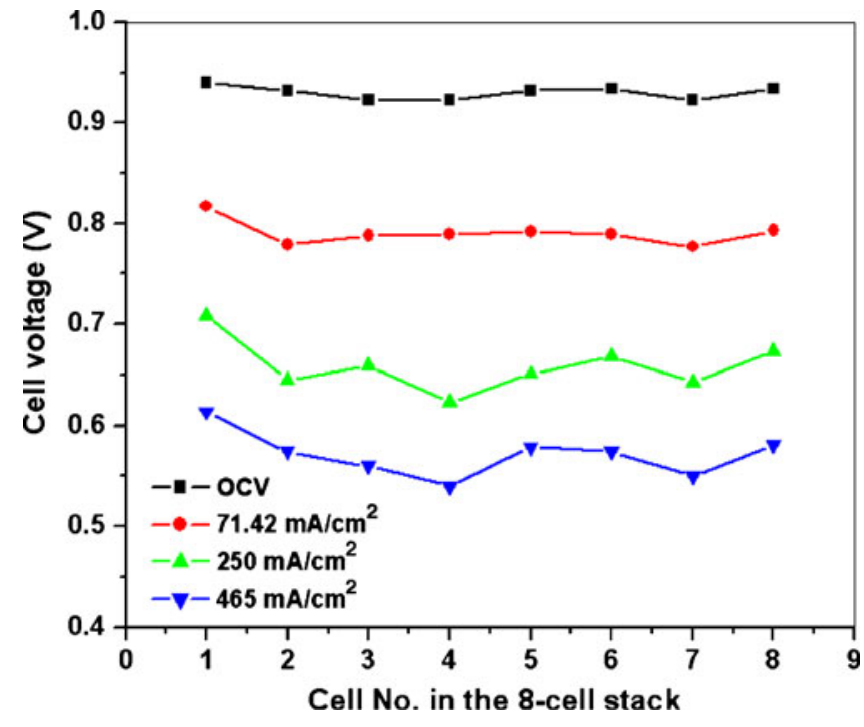

Figure 8. Individual cell voltages for the 8-cell Nafionsilica PEFC stack at varying load- current densities operating at $60^{\circ} \mathrm{C}$ without any external humidification.

attached to the stack so as to absorb both heat and product water from the fuel-cell stack. Figures $7 \mathrm{a}$ and $\mathrm{b}$ show variations in power and power density for such a Nafion- $-\mathrm{SiO}_{2}$ PEFC stack operating with $\mathrm{H}_{2}$ in deadend mode and air without external humidification. The maximum power output from the PEFC stack is found to be $325 \mathrm{~W}\left(290 \mathrm{~mW} \mathrm{~cm}^{-2}\right)$ at a load current of $85 \mathrm{~A}$ $\left(607 \mathrm{~mA} \mathrm{~cm}^{-2}\right)$. Figure 8 shows cell-to-cell voltage for the PEFC stack at OCV, and at load current-densities of $71 \mathrm{~mA} \mathrm{~cm}^{-2}, 250 \mathrm{~mA} \mathrm{~cm}^{-2}$ and $465 \mathrm{~mA} \mathrm{~cm}^{-2}$. The cell-to-cell voltage variation is fairly uniform at $\mathrm{OCV}$ and $71 \mathrm{~mA} \mathrm{~cm}^{-2}$ while a variation within $\pm 25 \mathrm{mV}$ is seen at $250 \mathrm{~mA} \mathrm{~cm}^{-2}$ and $465 \mathrm{~mA} \mathrm{~cm}^{-2}$.

In brief, the present study is a detailed investigation on the durability of Nafion-1135, Nafion-silica and Nafion-MZP composite membranes in a PEFC operating at $100^{\circ} \mathrm{C}$ and $15 \% \mathrm{RH}$. The presence of silica and MZP as filler materials for the composite membrane helps absorbing water that acts as a water reservoir to keep the membrane hydrated even at elevated temperatures and low RH values. This helps the PEFCs to sustain periods of inlet-stream draught without excessive loss in membrane conductivity. A PEFC stack with Nafion-silica composite membrane is assembled wherein the humidification exigencies are avoided that help reducing the system complexity and hence its cost.

\section{Conclusions}

The stability and durability of PEFCs employing pristine Nafion-1135, Nafion-SiO 2 and Nafion-MZP composite membranes are evaluated at an elevated temperature and at a reduced RH value. It is surmised that the properties such as reduced gas-crossover, fast reaction-kinetics and superior fuel-cell-performance with Nafion-SiO${ }_{2}$ and Nafion-MZP composite membranes help prolonged operation of PEFCs without any external humidification. The best performance is achieved with the PEFC operating with Nafion- $\mathrm{SiO}_{2}$ composite membrane. An 8-cell PEFC stack employing Nafion- $\mathrm{SiO}_{2}$ composite membrane is performance evaluated with $\mathrm{H}_{2}$ and atmospheric air without any external humidification, and is found to deliver a maximum power output of $325 \mathrm{~W}$.

\section{Acknowledgement}

Financial support from the Council of Scientific and Industrial Research (CSIR), New Delhi is gratefully acknowledged.

\section{References}

1. Xie J, Wood D L, More K L, Atanassov P and Borup R L 2005 J. Electrochem. Soc. 152 A1011

2. Darling R M and Meyers J P 2003 J. Electrochem. Soc. 150 A 1523

3. Wang X, Kumar R and Myers D J 2006 Electrochem. Solid-State Lett. 9 A225

4. Yasuda K, Taniguchi A, Akita T, Ioroi T and Siroma Z 2006 Phys. Chem. Chem. Phys. 8746

5. Roen L M, Paik C H and Jarvi T D 2004 Electrochem. Solid-State Lett. 7 A19

6. Li W and Lane A M 2010 Electrochim. Acta 556926

7. Srinivasan S, Mosdale R, Stevens P and Yang C 1999 Annu. Rev. Energy Environ. 24281

8. Narayanan S R, Valdez T I and Firdosy S $2009 \mathrm{~J}$. Electrochem. Soc. 156 B 152

9. Knights S D, Colbow K M, St-Pierre J and Wilkinson D P 2004 J. Power Sources 127127

10. Kocha S S, Yang J D and Yi J S 2006 AIChE Journal 52 1916

11. Borup R, Meyers J, Pivovar B, Kim Y S, Mukundan R, Garland N, Myers D, Wilson M, Garzon F, Wood D, Zelenay P, More K, Stroh K, Zawodzinski T, Boncella X J, McGrath J E, Inaba O M, Miyatake K, Hori M, Ota K, Ogumi Z, Miyata S, Nishikata A, Siroma Z, Uchimoto Y, Yasuda K, Kimijima K and Iwashita N 2007 Chem. Rev. 1073904

12. Abdullah A M, Okajima T, Kitamura F and Ohsaka T 2008 Electrochemistry Commun. 101732

13. Kinumoto $T$, Inaba $M$, Nakayama $\mathrm{Y}$, Ogata $\mathrm{K}$, Umebayashi R, Tasaka A, Iriyama Y, Abe T and Ogumi Z 2006 J. Power Sources 1581222

14. Mittal V O, Kunz H R and Fenton J M 2006 ECS Trans. 1275

15. Liu H, Gasteiger H A, Laconti A and Zhang J 2006 ECS Trans. 1283

16. Chen J, Asano M, Yamaki T and Yoshida M $2006 \mathrm{~J}$. Appl. Polym. Sci. 1004565 
17. Endoh E 2006 ECS Trans. 39

18. Collier A, Wang H, Yuan X Zi, Zhang $\mathrm{J}$ and Wilkinson D P 2006 Int. J. Hydrogen Energy 311838

19. Inaba M, Kinumoto $\mathrm{T}$, Kiriake M, Umebayashi R, Tasaka A and Ogumi Z 2006 Electrochim. Acta 515746

20. Teranishi K, Kawata K, Tsushima S and Hirai S 2006 Electrochem. Solid-State Lett. 9 A475

21. Cheng X, Zhang J, Tang Y, Song C, Shen J, Song D and Zhang J 2007 J. Power Sources 16725

22. Sahu A K, Selvarani G, Pitchumani S, Sridhar P and Shukla A K 2007 J. Electrochem. Soc. 154 B123

23. Sahu A K, Pitchumani S, Sridhar P and Shukla A K 2009 Fuel Cells 9139

24. Jiang R, Kunz H R and Fenton J M 2006 J. Membr. Sci. 272116

25. Lin C W, Thangamuthu R and Chang P H 2005 J. Membr. Sci. 254197
26. Aparicio M, Castro Y and Duran A 2005 Solid State Ionics 176333

27. Adjemian K T, Lee S J, Srinivasan S, Benziger J and Bocarsly A B 2002 J. Electrochem. Soc. 149 A256

28. Li L, Moore C W, Bhusari D, Prakash S and Kohl P A 2006 J. Electrochem. Soc. 153 A343

29. Costamagna P, Yang C, Bocarsly A B and Srinivasan S 2002 Electrochim. Acta 471023

30. Damay F and Klein L C 2003 Solid State Ionics 162-163 261

31. Alberti G, Casciola M, Pica M, Tarpanelli $\mathrm{T}$ and Sganappa M 2005 Fuel Cells 5366

32. Borup R L, Davey J R, Garzon F H, Wood D L and Inbody M A 2006 J. Power Sources 16376

33. Sahu A K, Bhat S D, Pitchumani S, Sridhar P, Vimalan V, George C, Chandrakumar N and Shukla A K 2009 J. Membr. Sci. 345305 